\title{
MCL-1 inhibitor AMG 397
}

National Cancer Institute

\section{Source}

National Cancer Institute. MCL-1 inhibitor AMG 397. NCI Thesaurus. Code C156740.

An inhibitor of induced myeloid leukemia cell differentiation protein (myeloid cell leukemia-

1; Mcl-1; BCl2-L-3), with potential pro-apoptotic and antineoplastic activities. Upon administration, MCL-1 inhibitor AMG 397 targets and binds to Mcl-1, thereby preventing the binding of $\mathrm{Mcl}-1$ to and inactivation of certain pro-apoptotic proteins. This promotes apoptosis of cells overexpressing Mcl-1. Mcl-1, an anti-apoptotic protein belonging to the B-cell lymphoma 2 ( $\mathrm{Bcl}-2)$ family of proteins, is upregulated in cancer cells and promotes tumor cell survival. 